\title{
Synthesis of $\mathrm{KAlSiO}_{4}$ by Hydrothermal Processing on Biotite Syenite and Dissolution Reaction Kinetics
}

\author{
Jiangyan Yuan ${ }^{1,2}$, Hongwen Ma ${ }^{2, *}$, Zheng Luo ${ }^{2}, \mathrm{Xi} \mathrm{Ma}^{3}$ and Qian Guo ${ }^{1}$ \\ 1 State Key Laboratory of Lithospheric Evolution, Institute of Geology and Geophysics, Chinese Academy of \\ Sciences, Beijing 100029, China; yuanjy@mail.iggcas.ac.cn (J.Y.); guoqian@mail.iggcas.ac.cn (Q.G.) \\ 2 Beijing Key Laboratory of Materials Utilization of Nonmetallic Minerals and Solid Wastes, School of Materials \\ Science and Technology, China University of Geosciences, Beijing 100083, China; luo.zheng1988@163.com \\ 3 State Key Laboratory of Earthquake Dynamics, Institute of Geology, China Earthquake Administration, \\ Beijing 100029, China; maxi@ies.ac.cn \\ * Correspondence: mahw@cugb.edu.cn
}

Citation: Yuan, J.; Ma, H.; Luo, Z.; $\mathrm{Ma}$, X.; Guo, Q. Synthesis of $\mathrm{KAlSiO}_{4}$ by Hydrothermal Processing on Biotite Syenite and Dissolution Reaction Kinetics. Minerals 2021, 11, 36. https://doi.org/10.3390/ $\min 11010036$

Received: 20 November 2020 Accepted: 26 December 2020 Published: 30 December 2020

Publisher's Note: MDPI stays neutral with regard to jurisdictional clai$\mathrm{ms}$ in published maps and institutional affiliations.

Copyright: (C) 2020 by the authors. Licensee MDPI, Basel, Switzerland. This article is an open access article distributed under the terms and conditions of the Creative Commons Attribution (CC BY) license (https:// creativecommons.org/licenses/by/ $4.0 /)$.

\begin{abstract}
To make potassium from K-bearing rocks accessible to agriculture, processing on biotite syenite powder under mild alkaline hydrothermal conditions was carried out, in which two types of KAlSiO4 were obtained successfully. The dissolution-precipitation process of silicate rocks is a significant process in lithospheric evolution. Its effective utilization will be of importance for realizing the comprehensiveness of aluminosilicate minerals in nature. Two kinds of $\mathrm{KAlSiO}_{4}$ were precipitated in sequence during the dissolution process of biotite syenite. The crystal structures of two kinds of $\mathrm{KAlSiO}_{4}$ were compared by Rietveld structure refinements. The kinetics model derived from geochemical research was adopted to describe the dissolution behavior. The reaction order and apparent activation energy at the temperature range of $240-300{ }^{\circ} \mathrm{C}$ were 2.992 and $97.41 \mathrm{~kJ} / \mathrm{mol}$, respectively. The higher dissolution reaction rate of K-feldspar mainly relies on the alkaline solution, which gives rise to higher reaction order. During the dissolution-precipitation process of K-feldspar, two types of KAlSiO4 with different crystal structure were precipitated. This study provides novel green chemical routes for the comprehensive utilization of potassium-rich silicates.
\end{abstract}

Keywords: K-feldspar; kalsilite; kinetics; hydrothermal processing

\section{Introduction}

The continuous growth of the world population causes a lack of crops production. The global demand for potassium will appear as a rising tendency in the coming several decades [1]. At present, the potassium salt is obtained mainly from water-soluble potassium salt resources [2]. The imports of potash have increased in China year-by-year. The recovery of potassium from potassium-rich rocks has attracted more attention in recent years and will become a promising way to relieve the shortage of potassium from a green chemistry perspective. Therefore, the use of water-insoluble potassium resources, such as potassium feldspar, nepheline, and muscovite, is a guarantee for Chinese agriculture sustainable development [3]. Feldspars consisting of a group of minerals are fairly common in igneous rocks such as granites, gneisses and schists, as well as metamorphic and some sedimentary rocks, constituting $60 \%$ of both the continental and the oceanic crusts of our planet [2]. Thereby, K-feldspar was suggested as a source of potassium for agriculture in the beginning of the twentieth century [3,4].

The approach based on the use of ground K-feldspar is simple and involves minimum energy consumption, but it has not yet been successfully implemented in mainstream agriculture, mainly because of the extremely slow rate of potassium released from the minerals [5,6]. Recently, Ciceri and Allanore [7] measured the leaching rate of $\mathrm{K}^{+}$ions from syenite in a microfluidic environment and demonstrated that $\mathrm{K}^{+}$is available at a higher rate than that observed with conventional apparatuses. Therefore, they thought 
that the research of potassium rock is important particularly for tropical soils and countries that cannot afford or access traditional potassium fertilizers. The stable structure of Kfeldspar makes it difficult to release $\mathrm{K}^{+}$and, therefore, it cannot be used as a fertilizer in the soil directly [8]. The production of potassium salts from potassium-rich rocks should meet the following requirements: lower energy to destroy the structure of potassium feldspar, efficient decomposition process, comprehensive utilization of $\mathrm{K}_{2} \mathrm{O}, \mathrm{Al}_{2} \mathrm{O}_{3}$, and $\mathrm{SiO}_{2}$ resources, as well as clean production [9-11]. Therefore, the conversion of $\mathrm{K}_{2} \mathrm{O}$ in potassic rocks (potassium feldspar) into the structure that is easy to be dissolved in the soil is the main goal. An additional goal is to convert the byproducts of $\mathrm{Al}_{2} \mathrm{O}_{3}$ and $\mathrm{SiO}_{2}$ into useful substances leading to comprehensive and cost-effective utilization of potassic rocks.

The slow-release $\mathrm{K}^{+}$fertilizer in kalsilite-type attracts lots of attention among researchers, such as $\mathrm{K}_{2} \mathrm{MgSiO}_{4}, \mathrm{~K}_{2} \mathrm{MgSi}_{3} \mathrm{O}_{8}, \mathrm{~K}_{2} \mathrm{MgSi}_{5} \mathrm{O}_{12}, \mathrm{~K}_{4} \mathrm{Mg}_{2} \mathrm{Si}_{5} \mathrm{O}_{14}$, and $\mathrm{K}_{2} \mathrm{MgSi}_{3} \mathrm{O}_{8}$ [12-17]. The solubility results suggest the release of $\mathrm{K}_{2} \mathrm{O}$ of these compounds in $0.5 \mathrm{~mol} / \mathrm{L} \mathrm{HCl}(24-38 \%)$, citric acid $0.1 \mathrm{~mol} / \mathrm{L}(17-24 \%)$, and water (3-8\%), all of which reached the Chinese national standard of slow-release fertilizer and can function as slow-release fertilisers to supply K, $\mathrm{Mg}$, and Si nutrients for crops [16,18]. Owing to the lower resources reserves of kalsilite, the application of kalsilte in agriculture is limited. There are many different methods to synthesize kalsilite, such as the sol-gel method, solid-phase reaction method, and the hydrothermal method. Bogdanovicieni synthesized $\mathrm{KAlSiO}_{4}$ and $\mathrm{K}_{0.5} \mathrm{Na}_{0.5} \mathrm{AlSiO}_{4}$ using analytical grade reagents $\left(\mathrm{CH}_{3} \mathrm{COOK}, \mathrm{CH}_{3} \mathrm{COONa}, \mathrm{Al}\left(\mathrm{NO}_{3}\right)_{3} \cdot 9 \mathrm{H}_{2} \mathrm{O}\right.$ and $\left.\mathrm{SiO}_{2} \cdot 0.3207 \mathrm{H}_{2} \mathrm{O}\right)$ through the sol-gel method [19]. Kalsilite was obtained through the ion exchange of $\mathrm{K}^{+}$ and LTA zeolite by Dimitrijevic et al. [20]. Compared with these synthesis methods, it is more economical and convenient for the synthesis of kalsilite to utilize the hydrothermal method. The synthesis and transformation mechanism of kalsilite from kaolinite in $\mathrm{KOH}$ solution were reported by Becerro et al. [21]. However, compared to those compounds, the synthesis of $\mathrm{KAlSiO}_{4}$ is easier and of lower energy consumption for the green and clean production of $\mathrm{K}$-feldspar $\left(\mathrm{KAlSi}_{3} \mathrm{O}_{8}\right)$.

Dissolution and precipitation process of feldspars are of importance in the formation of zeolites and clay minerals as well as the hydrothermal transformation process of Kfeldspar. There are many factors influencing the dissolution rates of feldspar both in nature and laboratory experiments, such as ionic strength, temperature, $\mathrm{pH}$, fluid saturation state, and so on [22,23]. Here, we mainly use the coupled process to transform the potassium from K-feldspar into secondary mineral (kalsilite) in order to enhance potassium utilization efficiency in soil [24]. Our team has long-term research on the preparation of potassium salts and fertilizer from potassic rocks in order to realize the green utilization of potassic rocks [3-6,25-28], mainly including the soda sintering method and hydrothermal alkaline digestion. In our previous study, the dissolution products of potassic rocks were investigated in different solutions to prepare potassic salts. Most of them focus on optimizing hydrothermal treatment techniques of potassic rocks in order to realize the maximum utilization of resources and clean production $[29,30]$. The reaction rate plays a key role in influencing the efficiency of preparation techniques and dissolution process. The dissolution kinetics study will provide an important theoretical basis for the hydrothermal reaction and promote potassium preparation techniques development. Here, a potassium-rich biotite syenite powder mainly composed of K-feldspar was collected as the raw material in this study. Two types of $\mathrm{KAlSiO}_{4}$ were prepared during the dissolution and precipitation process of K-feldspar, the reaction kinetics of which was analyzed using the geochemical models. It will provide a new insight for separating potassium from the minerals which were difficult to decompose.

\section{Experiment}

\subsection{Materials}

The biotite syenite bulk sample (XS-16) used in this study was collected from Xiyuanxia village in Rongcheng County of Shandong province, China. The biotite syenite powder (XS-16) was obtained by handpicking and then crushed, ground, ball-milled and passed 
through a 200-mesh smaller than $75 \mu \mathrm{m}$ in diameter. The chemical composition of XS16 determined by wet chemical analysis and electron microprobe results were shown in Table $1[4,25,26,31]$. According to the principle of mass balance and MIFORM F90 software (Beijing Key Laboratory of Materials Utilization of Nonmetallic Minerals and Solid Wastes, Beijing, China) [32], the main phase of XS-16 was microcline with the chemical formula of $\mathrm{K}_{1.000} \mathrm{Na}_{0.045} \mathrm{Ca}_{0.002}\left[\mathrm{Fe}^{3+}{ }_{0.005} \mathrm{Ti}_{0.003} \mathrm{Al}_{0.992} \mathrm{Si}_{2.987} \mathrm{O}_{8}\right]$ and its content was $88.1 \mathrm{wt} . \%$, the accessory minerals were: biotite (4.6 wt.\%), quartz (5.2 wt.\%) and others (2.1 wt.\%). Potassium hydroxide ( $85 \%$, analytical reagent grade) was supplied by Beijing Modern Eastern Finechemical Co., Ltd., Beijing, China. The deionized water produced in the local laboratory was used in the experiments.

Table 1. The chemical compositions of biotite syenite and microprobe analysis of microcline (wt.\%).

\begin{tabular}{ccccccccccccc}
\hline Sample & $\mathrm{SiO}_{\mathbf{2}}$ & $\mathrm{TiO}_{\mathbf{2}}$ & $\mathbf{A l}_{\mathbf{2}} \mathbf{O}_{\mathbf{3}}$ & $\mathbf{T F e}_{\mathbf{2}} \mathbf{O}_{\mathbf{3}}$ & $\mathbf{M n O}$ & $\mathbf{M g O}$ & $\mathbf{C a O}$ & $\mathbf{N a}_{\mathbf{2}} \mathbf{O}_{2}$ & $\mathbf{K}_{\mathbf{2}} \mathbf{O}$ & $\mathbf{P}_{\mathbf{2}} \mathbf{O}_{\mathbf{5}}$ & $\mathbf{L O I}$ & $\mathbf{T o t a l}$ \\
\hline XS-16 & 64.84 & 0.29 & 17.95 & 0.83 & 0.01 & 0.65 & 0.36 & 0.63 & 14.15 & 0.08 & 0.47 & 100.24 \\
microcline & 63.84 & 0.08 & 17.99 & 0.14 & 0.04 & 0.02 & 0.03 & 0.50 & 16.76 & - & - & 99.39 \\
\hline \multicolumn{8}{c}{ Microcline composition is the average values of 17-point determinations by electron microprobe. }
\end{tabular}

\subsection{Experimental Procedure}

The reaction device used in this experiment has been described in our previous report [33]. In hydrothermal experiments, $15 \mathrm{~g}$ biotite syenite powder was dissolved in $\mathrm{KOH}$ solution (5-7 mol/L) with the solid to liquid ratio of $1 / 3$ in a $100 \mathrm{~mL}$ Teflon liner assembled in a steel hydrothermal autoclave installed in a temperature-controlled homogenous reactor at $240 \sim 300{ }^{\circ} \mathrm{C}$ for $0.5 \sim 8 \mathrm{~h}$ with a rotation speed of $6 \mathrm{r} / \mathrm{s}$. The reaction pressure was the automatic pressure. After hydrothermal treatment, the separation of solid-liquid phase was realized by filtration and washing with deionized water. The solid precipitation was obtained by drying at $105^{\circ} \mathrm{C}$ for $16 \mathrm{~h}$.

\subsection{Characterization}

The X-ray diffractometer (XRD) patterns of K-feldspar powder and the solid products obtained under different conditions were recorded by a D8 Advance X-ray diffractometer with $\mathrm{Cu} \mathrm{K} \alpha$ radiation $(\lambda=0.154 \mathrm{~nm}, 40 \mathrm{kV} / 40 \mathrm{~mA}$ ) (Bruker Scientific Instruments, Germany). The powder diffraction data were analyzed using a computer software General Structure Analysis System (GSAS) package (Los Alamos National Laboratory, University of California, Oakland, CA, USA) [34]. The chemical composition of samples was investigated by WD-X-ray fluorescence spectrometer (XRF, Malvern Panalytical, Almelo, The Netherlands). The morphology of samples was examined by using a Zeiss Gemini 450 scanning electron microscope (SEM) (Carl Zeiss, Germany). Fourier-transform infrared spectra (FTIR) of samples were collected by a Perkin Elmer 2000 in the $4000 \sim 400 \mathrm{~cm}^{-1}$ region using potassium bromide as the diluent and binder. Potassium, aluminum, sodium, and silicon ions' concentration in solutions were measured by Inductively Coupled Plasma-Atomic Emission Spectrometry (ICP-AES) with a wavelength range at 166-847 nm (ICAP 7600, Thermo Fisher Scientific, Waltham, MA, USA).

\section{Results and Discussion}

\subsection{Synthesis and Characterization of Two Kinds of $\mathrm{KAlSiO}_{4}$}

Two kinds of $\mathrm{KAlSiO}_{4}$ were precipitated by utilizing the dissolution-precipitation process of biotite syenite. Figure 1 shows the XRD patterns of the products obtained after hydrothermal reaction at $260{ }^{\circ} \mathrm{C}$ for $0.5-8 \mathrm{~h}$ (named as XS-K-0.5h, XS-K-1h XS-K$8 \mathrm{~h}$, respectively). In our study, we found that the intermediate phase was well-matched with the megakalsilite (ICDD-PDF No. 00-054-1123 (2020)) of $P 6_{3}$ [35], which is similar to the crystal structure of $\mathrm{MZnPO}_{4}(\mathrm{M}=\mathrm{Na}, \mathrm{K}, \mathrm{Rb}, \mathrm{Cs})$ as described in the report of Andratschke [36], so the intermediate product was abbreviated as MEK. The diffraction peaks of other product samples can be well indexed into microcline (ICDD-PDF No. 00- 
019-0932 (2020)) with the space group of $P \overline{1}$, kalsilite (ICDD-PDF No. 00-011-0579 (2020)) of $P 6_{3}$, suggesting that the increase of reaction time is caused the difference of products, but both have the same space group. The formation of precipitation phases occurs only when the bulk solution is oversaturated. In the report of Hellmann \& Tisserand [37], only when $\Delta G \geq-25 \mathrm{~kJ} \cdot \mathrm{mol}^{-1}$, the formation of secondary phases was thermodynamically feasible. It is shown that $\mathrm{K}$-feldspar powder presents slate-like morphology with layers of cleavage on the sides (Figure 2a). Visible corrosive pitting was generated at the originally smooth and plate-like surface of K-feldspar (Figure $2 b, c$ ) and after $0.5 \mathrm{~h}$ will increase the contact area between the $\mathrm{KOH}$ solution and $\mathrm{K}$-feldspar as well as accelerate the dissolution of K-feldspar further [38]. Table 2 gives the chemical composition of reaction products and calculated phase composition results. $\eta\left(\mathrm{SiO}_{2}\right)$ was calculated by Equation (1),

$$
\eta\left(\mathrm{SiO}_{2}\right)=\left[C\left(\mathrm{SiO}_{2}\right) \times V(\text { filtrate })\right] /\left[\omega\left(\mathrm{SiO}_{2}\right) \times M(\mathrm{XS}-16)\right] \times 100 \%
$$

where $\eta\left(\mathrm{SiO}_{2}\right)$ represents the leaching ratio of $\mathrm{SiO}_{2}$ from K-feldspar; $C\left(\mathrm{SiO}_{2}\right)$ is the concentration of $\mathrm{SiO}_{2}$ in the filtrate solution obtained from the hydrothermal reaction; $\omega\left(\mathrm{SiO}_{2}\right)$ denotes the mass fraction of $\mathrm{SiO}_{2}$ in XS-16. After reacting for $1 \mathrm{~h}$, reaction products were composed of microcline $(68 \%)$ and MEK $(32 \%)$, consistent with SEM results in Figure 2d, in which there are some small particles of MEK around massive bulk Kfeldspar with a lot of erosional pits in Figure 2d. With the extension of reaction time, the $\mathrm{K}$-feldspar disappeared and MEK formed completely with uniform and regular hexagram shapes (Figure 2f). After reacting for $4 \mathrm{~h}$, reaction products were composed of MEK $(42 \%)$ and Kls (58\%) as shown in Figure 2g, where the morphology consists of some hexagrams (MEK) and hexagonal flakes (Kls). Longer reaction time is beneficial to the crystallization of kalsilite, so the morphology of the product transformed into a hexagonal shape completely in Figure 2i.

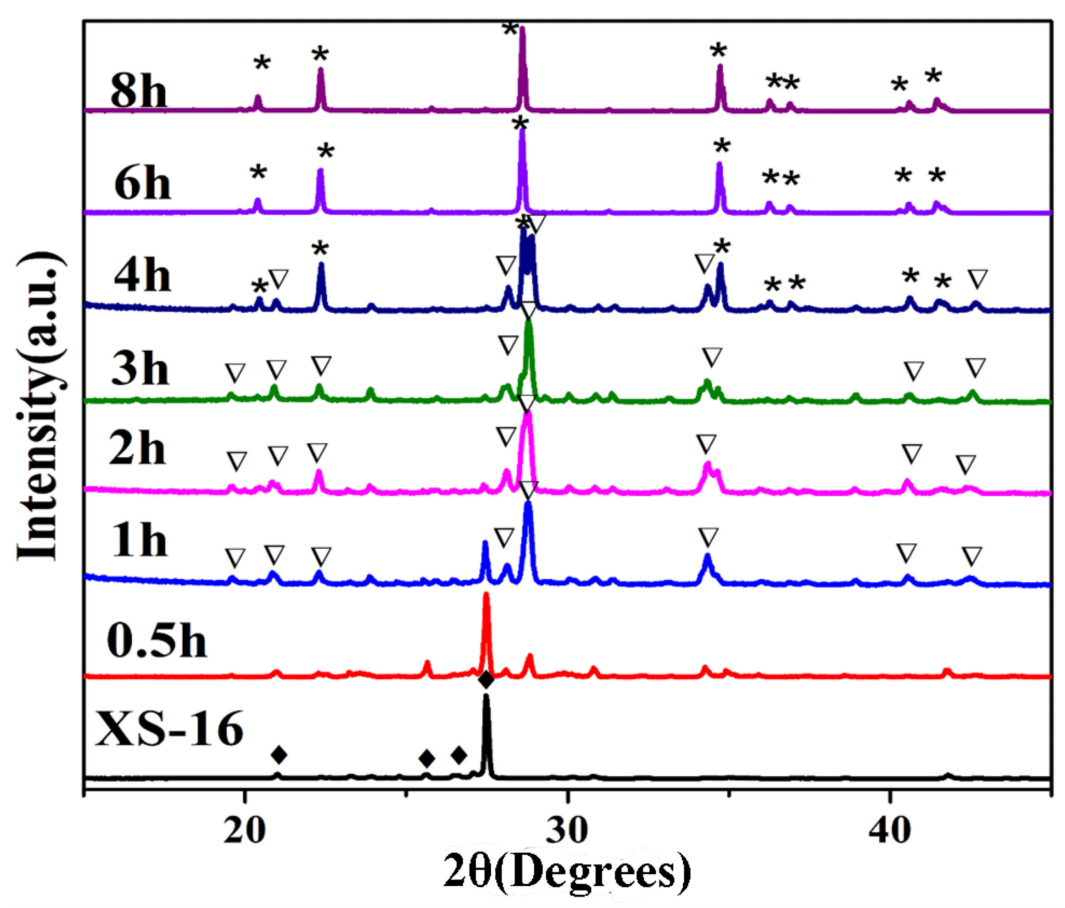

Figure 1. The XRD patterns of K-feldspar and precipitation samples obtained after the hydrothermal treatment of K-feldspar for $0.5 \mathrm{~h}, 1,2,3,4,6$ and $8 \mathrm{~h}$. $\checkmark$-microcline, $\nabla-\mathrm{MEK}, *-$ Kalsilite. 

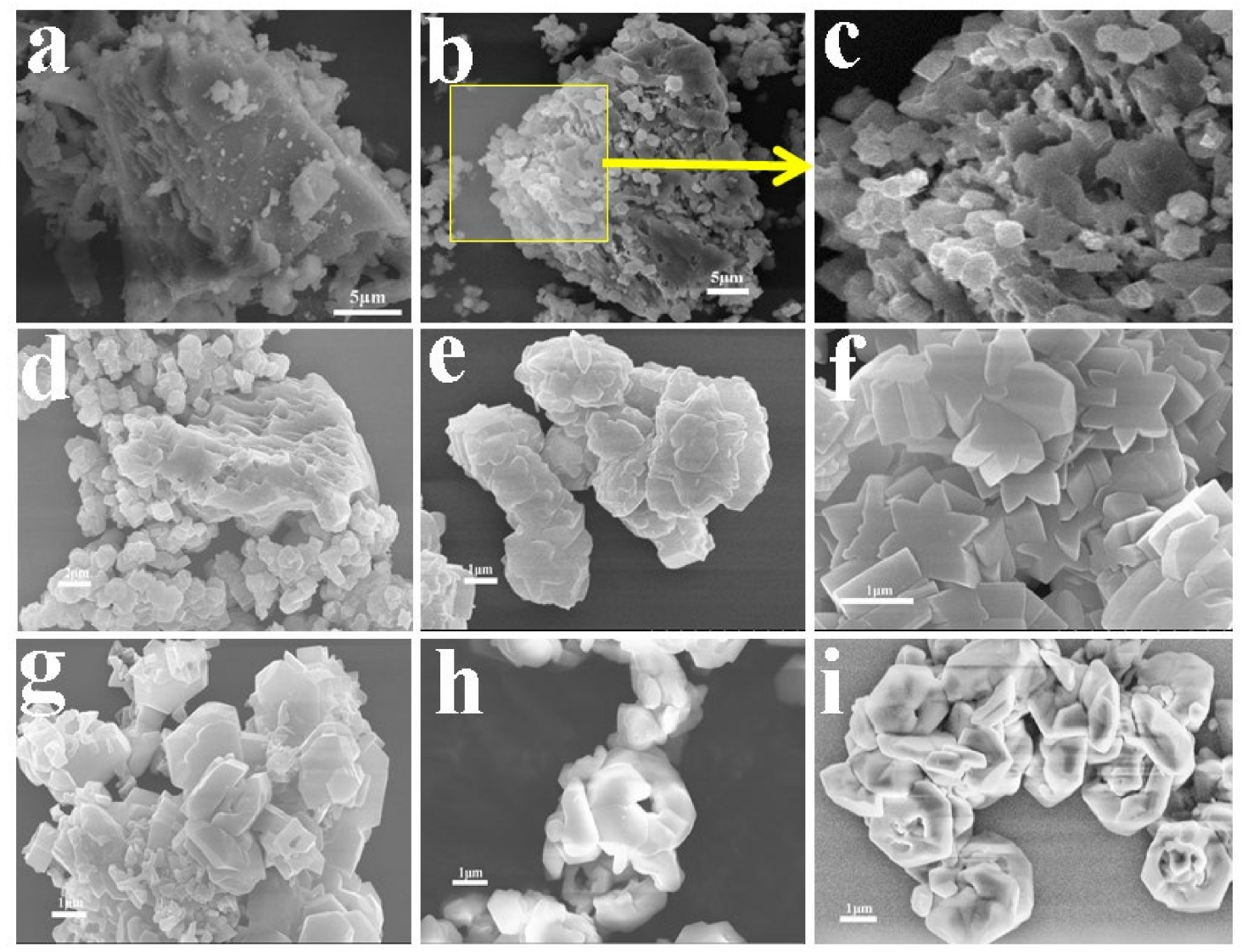

Figure 2. SEM images of K-feldspar (a) and the dissolution and precipitation products of K-feldspar in $\mathrm{KOH}$ solution for 0.5 $(\mathbf{b}, \mathbf{c}), 1$ (d), 2 (e), 3 (f), 4 (g), 6 (h) and 8 h (i).

Table 2. The chemical composition of precipitation samples obtained after hydrothermal treatment of K-feldspar (Micmicrocline, Kls—-kalsilite).

\begin{tabular}{|c|c|c|c|c|c|c|c|}
\hline Sample & Time/h & $\mathrm{SiO}_{2}$ & $\mathrm{~K}_{2} \mathrm{O}$ & $\mathrm{Al}_{2} \mathrm{O}_{3}$ & $\begin{array}{c}\mathrm{C} \\
\left(\mathrm{SiO}_{2}\right) / \mathrm{mol}^{-} \mathrm{L}^{-1}\end{array}$ & $\eta \mathrm{SiO}_{2}(\%)$ & Product Phase \\
\hline XS-K-1 & 1 & 44.98 & 21.53 & 28.77 & 2.062 & 57.52 & $\operatorname{Mic}(68 \%)+\operatorname{MEK}(32 \%)$ \\
\hline XS-K-2 & 2 & 38.60 & 28.83 & 30.66 & 2.278 & 63.54 & $\operatorname{Mic}(31 \%)+\operatorname{MEK}(69 \%)$ \\
\hline XS-K-3 & 3 & 38.89 & 28.46 & 30.35 & 2.269 & 63.27 & MEK \\
\hline XS-K-4 & 4 & 37.81 & 29.66 & 30.04 & 2.305 & 64.29 & $\operatorname{MEK}(42 \%)+\operatorname{Kls}(58 \%)$ \\
\hline XS-K-6 & 6 & 37.23 & 29.09 & 29.95 & 2.325 & 64.84 & Kls \\
\hline XS-K-8 & 8 & 37.69 & 29.12 & 30.47 & 2.310 & 64.41 & Kls \\
\hline
\end{tabular}

In order to seek a better understanding about the difference between the crystal structure of kalsilite and MEK, Rietveld structure refinements for two types of $\mathrm{KAlSiO}_{4}$ were carried out based on the GSAS program using the powder XRD data. Figure 3a,c displayed the Rietveld fit of the XRD pattern of kalsilite and MEK, and the final refined unit cell parameters are summarized in Tables 3 and 4. It is clear that all Bragg diffraction lines of kalsilite and MEK are assigned to the hexagonal system with space group $P 6_{3}$. The unit cell of MEK: $a=b=18.12930 \AA, c=8.48727 \AA, V=2415.809 \AA^{3}$, is more than ten times as large as that of kalsilite $\left(a=b=5.167334 \AA, c=8.712779 \AA, V=201.4744 \AA^{3}\right)$. The layers of $\left[\mathrm{TO}_{4}\right]$ tetrahedra forming six-membered rings (S6R) are perpendicular to the $c$ axis where the $\left[\mathrm{SiO}_{4}\right]$ tetrahedron is surrounded by four $\left[\mathrm{AlO}_{4}\right]$ tetrahedron and vice versa. It is obvious that all the rings in Figure $3 \mathrm{~d}$ have tetrahedra pointing alternately up and down, which is expressed as UDUDUD, where $U$ and D represent tetrahedral pointing up and down respectively. However, it is very different in Figure $3 b$, whose structure is based on two types of ring topologies, UDUDUD and UUUDDD [39]. Combining Figure 3 
and Table 4, we can obtain that the $\mathrm{K}$ atoms have six sites in MEK but only one in kalsilite. The different $\mathrm{K}$ sites were shown in Figure $3 \mathrm{~b}$. The $\mathrm{K}$ atoms of kalsilite and $\mathrm{K} 4$ atoms of MEK are arranged in the cell edge along $c$ axis. From the plane (0001), layers generated by interlaced S6R have several open tunnels, and $\mathrm{K} 2$ atoms are located in the center channel. The tunnels occupied by $\mathrm{K} 6$ and $\mathrm{K} 5$ next to the central channel and tunnels taken up by $\mathrm{K} 1$ and $\mathrm{K} 3$ off-center form the diagonal of metastable $\mathrm{KAlSiO}_{4}$ unit cell. The distances of Al-O and Si-O in kalsilite structure are 1.71 and $1.64 \AA$, respectively, which is different from the values of 1.75 and 1.61 in the report of Smith \& Bailey [40]. And the distances of $\mathrm{Al}-\mathrm{O}$ and Si-O in MEK were summarized in Table 5. The average bond lengths of Al-O and Si-O are 1.93 and $1.54 \AA$, respectively, which indicate an ordered distribution of silicon and aluminum in neighboring tetrahedra [35].
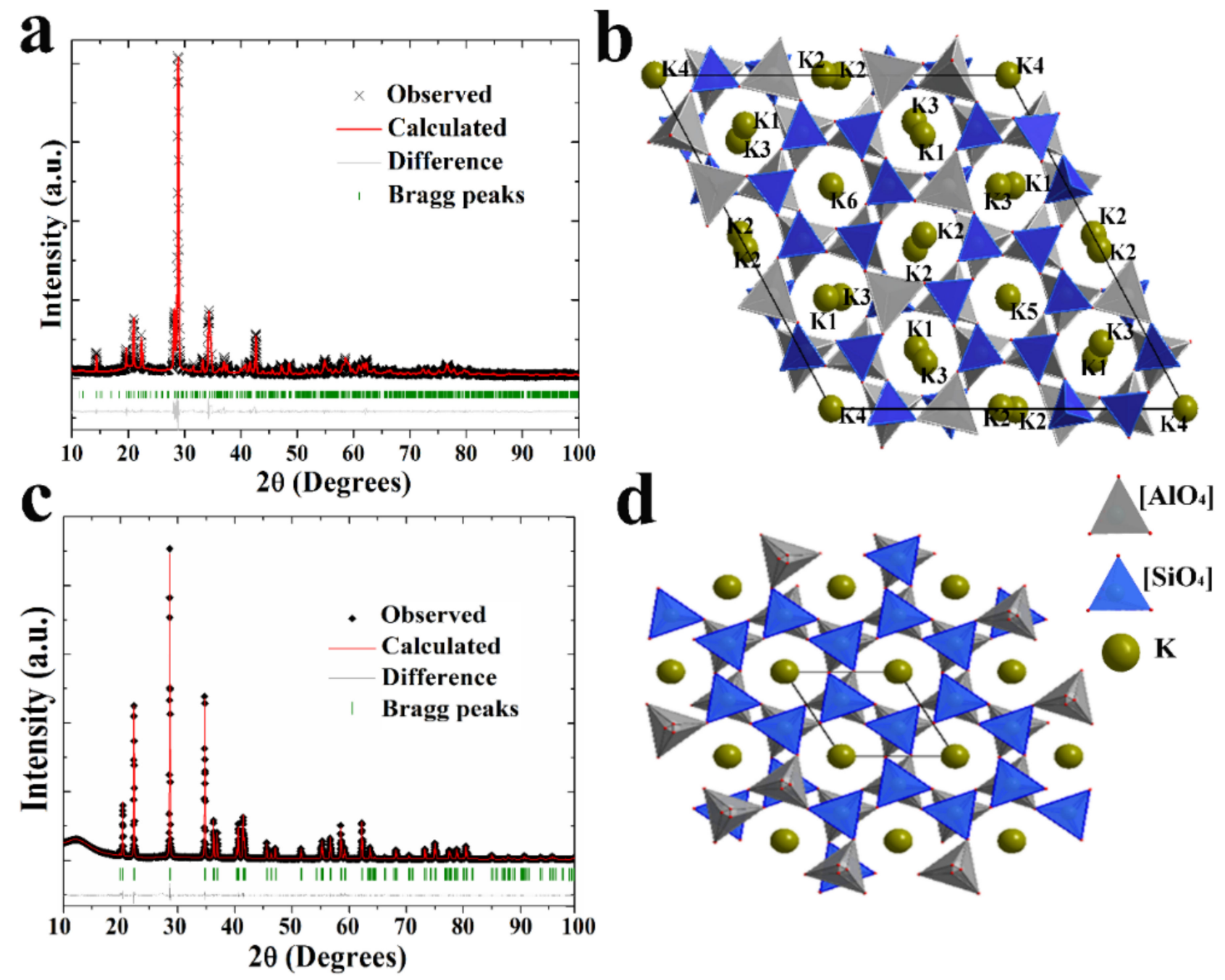

Figure 3. (a,c) Experimental, calculated XRD patterns and their difference for the Rietveld fits of MEK and kalsilite using the GSAS program; $(\mathbf{b}, \mathbf{d})$ the crystal structure of MEK and kalsilite based on the refinement result. 
Table 3. Fractional atomic coordinates, occupancies, and isotropic thermal parameters of kalsilite obtained from the GSAS Rietveld Refinement using X-ray powder diffraction data at room temperature.

\begin{tabular}{ccccc}
\hline Atom & $\mathbf{x}$ & $\mathbf{y}$ & $\mathbf{z}$ & Occupancy \\
\hline $\mathrm{K}$ & 0 & 0 & 0.2407 & 1.0 \\
$\mathrm{Al}$ & $1 / 3$ & $2 / 3$ & 0.0379 & 1.0 \\
$\mathrm{Si}$ & $1 / 3$ & $2 / 3$ & 0.4237 & 1.0 \\
$\mathrm{O} 1$ & 0.3831 & 0.9875 & 0.4858 & 1.0 \\
$\mathrm{O} 2$ & 0.3339 & 0.7155 & $1 / 4$ & $1 / 3$
\end{tabular}

space group: $P 6_{3}$-hexagonal; $a=b=5.16733(4) \AA, c=8.71277(9) \AA, V=201.474(4) \AA^{3} ; \alpha=\beta=90^{\circ}, \gamma=120^{\circ}$, $R_{\mathrm{wp}}(\%)=7.32, R_{\mathrm{p}}(\%)=4.50$.

Table 4. The refined positions of all the atoms and the lattice parameters of MEK.

\begin{tabular}{|c|c|c|c|c|}
\hline Atom & $x$ & $y$ & $z$ & Occupancy \\
\hline K1 & 0.1511 & 0.3310 & 0.9303 & 1.0 \\
\hline $\mathrm{K} 2$ & 0.5222 & 0.5196 & 0.9254 & 1.0 \\
\hline K3 & 0.3346 & 0.1392 & 0.9135 & 1.0 \\
\hline $\mathrm{K} 4$ & 0.0000 & 0.0000 & 0.4655 & 1.0 \\
\hline K5 & 0.3333 & 0.6667 & 0.4183 & 1.0 \\
\hline K6 & 0.3333 & 0.6667 & 0.9277 & 1.0 \\
\hline Al1 & 0.1673 & 0.1535 & 0.7300 & 1.0 \\
\hline $\mathrm{Al} 2$ & 0.6649 & 0.0019 & 0.1082 & 1.0 \\
\hline $\mathrm{Al} 3$ & 0.4989 & 0.3295 & 0.7370 & 1.0 \\
\hline $\mathrm{Al} 4$ & 0.3336 & 0.5023 & 0.7352 & 1.0 \\
\hline Si1 & 0.3287 & 0.3321 & 0.7182 & 1.0 \\
\hline $\mathrm{Si} 2$ & 0.3409 & 0.5067 & 0.1269 & 1.0 \\
\hline $\mathrm{Si} 3$ & 0.1726 & 0.1591 & 0.1204 & 1.0 \\
\hline Si4 & 0.4956 & 0.6689 & 0.6303 & 1.0 \\
\hline O1 & 0.1283 & 0.0795 & 0.2391 & 1.0 \\
\hline $\mathrm{O} 2$ & 0.0441 & 0.1803 & 0.4529 & 1.0 \\
\hline $\mathrm{O} 3$ & 0.3843 & 0.2958 & 0.6735 & 1.0 \\
\hline O4 & 0.3555 & 0.4147 & 0.6313 & 1.0 \\
\hline O5 & 0.1151 & 0.2009 & 0.1159 & 1.0 \\
\hline O6 & -0.0755 & 0.5481 & 0.1801 & 1.0 \\
\hline O7 & 0.2847 & 0.5400 & 0.1858 & 1.0 \\
\hline O8 & 0.4059 & 0.6121 & 0.6790 & 1.0 \\
\hline O9 & 0.2576 & 0.2238 & 0.2024 & 1.0 \\
\hline O10 & 0.5291 & 0.7519 & 0.7230 & 1.0 \\
\hline O11 & 0.4130 & 0.1104 & 0.6923 & 1.0 \\
\hline $\mathrm{O} 12$ & 0.2747 & 0.0359 & 0.1714 & 1.0 \\
\hline $\mathrm{O} 13$ & 0.1950 & 0.4789 & 0.4575 & 1.0 \\
\hline O14 & 0.3310 & 0.3435 & 0.8875 & 1.0 \\
\hline $\mathrm{O} 15$ & 0.1381 & 0.5802 & 0.2328 & 1.0 \\
\hline O16 & 0.6184 & 0.4725 & 0.4636 & 1.0 \\
\hline
\end{tabular}

space group: $P 6_{3}$-hexagonal; $a=b=18.12930 \AA, c=8.48727 \AA, V=2415.80(9) \AA^{3} ; \alpha=\beta=90^{\circ}, \gamma=120^{\circ}$; $R_{w p}(\%)=7.22, R p(\%)=5.23$.

Above all, two kinds of $\mathrm{KAlSiO}_{4}$ were precipitated during the dissolution process of biotite syenite under mild hydrothermal conditions, which is beneficial to realize the industrial utilization of this process. Compared to microcline, two kinds of $\mathrm{KAlSiO}_{4}$ obtained here are easier to be decomposed in the acid soil, which not only can supply potassium nutrition to plants but can ameliorate the soil with the porous structure. Although some large-pore potassium-rich zeolites such as L-types, A-types, and F-types can be prepared from the aluminosilicate residues or fusion products of K-feldspar, their treatment processings are complicated [27,29]. The synthesis of two types of $\mathrm{KAlSiO}_{4}$ was simpler and just involved one step, which fits with the green chemical production. Moreover, kalsilte also can be used as a heterogeneous catalyst for biodiesel production [41,42] and as an ingredient in dental ceramic materials [43,44]. 
Table 5. The bond lengths of Si-O and Al-O in MEK.

\begin{tabular}{|c|c|c|c|c|c|c|c|}
\hline Bond & $\begin{array}{c}\text { Bond Length } \\
\text { (Å) }\end{array}$ & Bonds & $\begin{array}{c}\text { Bond Length } \\
\text { (A) }\end{array}$ & Bond & $\begin{array}{c}\text { Bond Length } \\
\text { (Å) }\end{array}$ & Bond & $\begin{array}{c}\text { Bonds } \\
\text { Length ( } \mathrm{A})\end{array}$ \\
\hline $\mathrm{Si1}-\mathrm{O} 3$ & 1.51 & Si2-O7 & 1.51 & Al1-O1 & 1.96 & Al2-O6 & 1.93 \\
\hline Si1-O4 & 1.51 & Si2-O11 & 1.58 & Al1-O2 & 1.95 & Al2-O9 & 1.97 \\
\hline Si1-O12 & 1.48 & Si2-O15 & 1.55 & Al1-O5 & 1.89 & $\mathrm{Al} 2-\mathrm{O} 11$ & 1.94 \\
\hline Si1-O14 & 1.45 & Si2-O16 & 1.53 & Al1-O12 & 1.98 & $\mathrm{Al2}-\mathrm{O} 14$ & 1.89 \\
\hline Si3-O1 & 1.61 & Si4-O6 & 1.48 & Al3-O3 & 1.92 & Al4-O4 & 2.02 \\
\hline $\mathrm{Si3}-\mathrm{O} 2$ & 1.51 & Si4-O8 & 1.59 & Al3-O7 & 1.89 & Al4-O8 & 1.82 \\
\hline Si3-O5 & 1.57 & Si4-O10 & 1.53 & Al3-O13 & 2.00 & Al4-O10 & 1.80 \\
\hline Si3-O9 & 1.57 & Si4-O13 & 1.64 & Al3-O15 & 1.83 & Al4-O16 & 2.08 \\
\hline \multicolumn{4}{|c|}{ Average bond length of Si-O: $1.54 \AA$} & \multicolumn{4}{|c|}{ Average bond length of Al-O: $1.93 \AA$} \\
\hline
\end{tabular}

\subsection{Reaction Kinetics}

\subsubsection{Kinetic Model}

In a general sense, the dissolution reaction behavior of some minerals such as montmorillonite [45] and diaspore [46] in alkaline solution was described by the rate law reported by Lasaga et al. [47]:

$$
r=k_{0} \exp \left(-E_{\mathrm{a}} / \mathrm{RT}\right) a_{\mathrm{H}^{+}, \mathrm{OH}^{-}}^{n_{\mathrm{O}^{+}}, n_{\mathrm{OH}^{-}}} g(I) \prod_{i} a_{i}^{n_{i}} f\left(\Delta_{r} G\right)
$$

where $r$ represents the overall rate of reaction obtained directly from the quantity of $\mathrm{SiO}_{2}$ concentration released form the feldspar to solution; $k_{0}$ is the rate constant; $E_{\mathrm{a}}$ represents the apparent activated energy of overall reaction; $\mathrm{R}$ is gas constant; $T$ is the Kelvin temperature (K); $a_{\mathrm{H}^{+}, \mathrm{OH}^{-}}$stands for the activity of hydronium or hydroxyl ions, which reveals the influence of $\mathrm{pH}$ on the reaction rate; $g(I)$ represents the rate that may be independent of ionic strength; $\prod_{i} a_{i}^{n_{i}}$ accounts for the effect of the catalyzation or inhibition of possible aqueous species on the overall reaction; $\Delta_{r} G$ incorporates the Gibbs free energy driving the advance of the overall reaction, the increasing negative value of which always can show the thermodynamic "distance" form chemical equilibrium; $f\left(\Delta_{r} G\right)=0$ represents the chemical reaction is in the equilibrium state; $f\left(\left(\Delta_{r} G\right)=1\right.$ as $\Delta G_{r} \rightarrow \infty$, stands for a chemical reaction that is in the highly undersaturation state that is far from equilibrium. In the transition state theory (TST) [48], to describe the linear relationship between $r$ and $\Delta_{r} G$ in Equation (1), the following expression was introduced,

$$
f\left(\Delta_{r} G\right)=\left[1-\exp \left(\Delta_{r} G / R T\right)\right]
$$

However, a large amount of experiments shows the relationship between $r$ and $\Delta_{r} G$ is not fit with the linear TST rate law when the reaction is near equilibrium, especially in the dissolution process of feldspar [22,37]. Alekseyev [49] proposed a non-linear relationship,

$$
f\left(\Delta_{r} G\right)=\left\{1-\left[\exp \left(\Delta_{r} G / \mathrm{RT}\right)\right]^{p}\right\}^{q}
$$

where $p, q$ are the fitting parameters. In general, the Gibbs free energy of reaction deviating from the equilibrium can be expressed as:

$$
\Delta_{r} G=\mathrm{R} T \ln \left(Q / K_{\mathrm{eq}}\right)
$$

where $\mathrm{Q}$ is the activity quotient of the forward dissolution reaction and $K_{\mathrm{eq}}$ is the equilibrium constant. $Q=K_{\mathrm{eq}}$ at the chemical equilibrium means the forward reaction rate equals the reverse rate. 


\subsubsection{Kinetics Analysis}

In the reaction system, the dissolution of K-feldspar controlled the reaction rate. Assuming kalsilite has an ideal crystal structure, the dissolution of K-feldspar and precipitation of kalsilite are expressed as follows:

$$
\mathrm{KAlSi}_{3} \mathrm{O}_{8}+2 \mathrm{OH}^{-}+2 \mathrm{H}_{2} \mathrm{O} \rightarrow \mathrm{KAlSiO}_{4}+2 \mathrm{H}_{3} \mathrm{SiO}_{4}{ }^{-}
$$

In the reaction (R1), the release ratio of $\mathrm{SiO}_{2}$ from $\mathrm{K}$-feldspar can be used to provide a measurement for the dissolution rate of K-feldspar with the following equation:

$$
\mathrm{X} \%=\left[C\left(\mathrm{SiO}_{2}\right) \times V(\text { filtrate })\right] /\left[2 / 3 \times w\left(\mathrm{SiO}_{2}\right) \times \mathrm{M}(\mathrm{XS}-16)\right] \times 100 \%
$$

where $\mathrm{C}\left(\mathrm{SiO}_{2}\right)$ represents the concentration of $\mathrm{SiO}_{2}$ in filtrate $(\mathrm{g} / \mathrm{L}) ; V$ (filtrate) represents the filtrate volume; $w\left(\mathrm{SiO}_{2}\right)$ is the mass fraction of $\mathrm{SiO}_{2}$ in XS-16; M (XS-16) represents the mass of XS-16 added into the reaction (R1). Thermodynamic parameters for mineral end-members were referred from Holland et al. [50]. Activities and Gibbs free energy were calculated by the mixed solvent electrolyte (MSE) model [51]. Detailed methods for DG are referred from the report of Liu et al. [27] from our team.

The dissolution ratio of K-feldspar shows an obvious upward trend during the initial $90 \mathrm{~min}$ and higher temperature indicates a greater dissolution rate (Figure 4a). After $270 \mathrm{~min}$, the dissolution ratio of K-feldspar at 260 and $280{ }^{\circ} \mathrm{C}$ increases to $84.6 \%$ and $89.2 \%$ for $270 \mathrm{~min}$, respectively, and then remains relatively stable. The reaction at $300{ }^{\circ} \mathrm{C}$ reach equilibrium $(90.05 \%)$ at $90 \mathrm{~min}$, indicating higher temperature will make the dissolution ratio of K-feldspar reaching equilibrium quicker (Figure 4a). For a different $\mathrm{KOH}$ concentration, a higher value makes greater dissolution ratio of $\mathrm{K}$-feldspar at $260^{\circ} \mathrm{C}$, indicating more $\mathrm{OH}^{-}$is beneficial to the dissolution and structure breakdown of K-feldspar [52]. The reaction rate of $\mathrm{K}$-feldspar can be expressed in the following equation:

$$
r=\frac{\mathrm{d} X}{\mathrm{~d} T}
$$

In the report of Hellmann \& Tisserand [37], the curve of $r-\Delta G$ consists of three parts, $-150 \leq \Delta \mathrm{G} \leq-70 \mathrm{~kJ} \cdot \mathrm{mol}^{-1}$ is far from equilibrium; $-70 \leq \Delta \mathrm{G} \leq-25 \mathrm{~kJ} \cdot \mathrm{mol}^{-1}$ represents transition equilibrium regime; $\Delta \mathrm{G} \geq-25 \mathrm{~kJ} \cdot \mathrm{mol}^{-1}$ is closer to equilibrium. In general, more negative the values of $\Delta \mathrm{G}$ are, the further from equilibrium reactions are. In this study, all $\Delta G$ values are over $-25 \mathrm{~kJ} \cdot \mathrm{mol}^{-1}$, suggesting that high reaction temperature and basic environment can accelerate the reaction rate. The curve of $r-\Delta G$ reported by Hellmann and Tisserand [37] is highly non-linear and has a gentler slope at $150{ }^{\circ} \mathrm{C}$ and $\mathrm{pH} 9.2$ than that in the report of Burch et al. [22] at $80^{\circ} \mathrm{C}$ and $\mathrm{pH} 8.8$, which can explain well why the tendency of all $r-\Delta G$ relationships in this study is non-linear and sigmoidal at temperature $\geq 240^{\circ} \mathrm{C}$ and $\mathrm{pH}>12$. As shown in Figure $4 \mathrm{c}, \mathrm{d}$, the $r$ is greater at a higher temperature and higher concentration of $\mathrm{KOH}$ when the reactions have the same values of $\Delta G$.

The specific surface area (A) at different times is not able to be obtained synchronously, so the specific surface area $\mathrm{A}$ is assumed as a constant value. In Equation (R1), only $\mathrm{OH}^{-}$ions influence the reaction activity in the reactant. At a given temperature, $K_{0}$ is a constant relevant to A and $E_{\mathrm{a}}$. Equation (1) can be replaced by Equations (8) and (9) is the combination of Equations (4) and (9).

$$
\begin{gathered}
K_{0}=k_{0} A \exp \left(-E_{a} / \mathrm{R} T\right) \\
r=K_{0} a_{\mathrm{OH}^{-}}^{n} f\left(\Delta_{\mathrm{r}} G\right) \\
r=K_{0} a_{\mathrm{OH}^{-}}^{n}\left\{1-\left[\exp \left(\mathrm{m} \Delta_{\mathrm{r}} G / \mathrm{R} T\right)\right]^{p}\right\}^{q}
\end{gathered}
$$



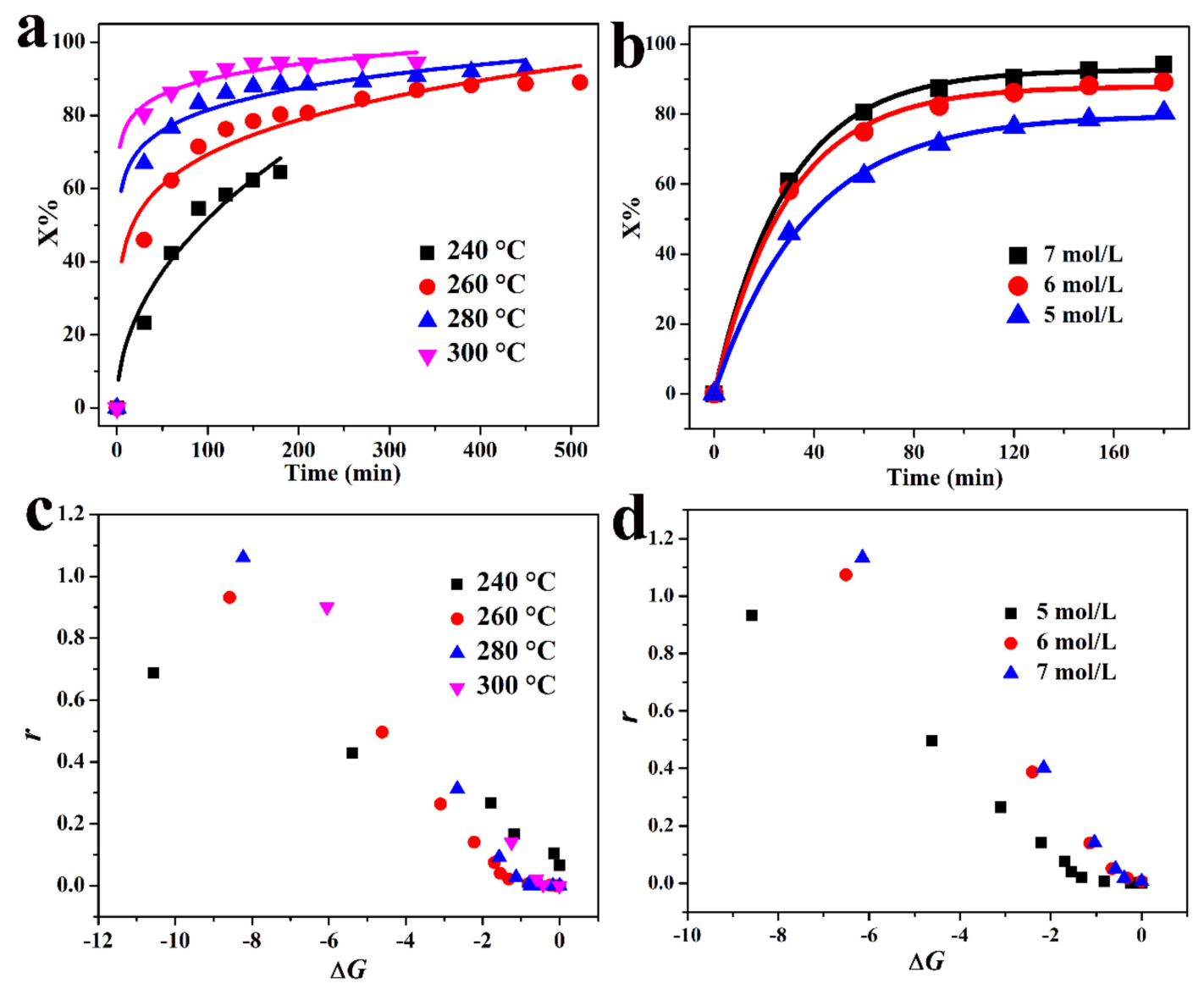

Figure 4. $X$-t relationship (a,b) and $r-\Delta_{\mathrm{r}} G$ correlation (c,d) for reaction (R1) at different reaction temperatures and concentrations of $\mathrm{KOH}$.

Considering the mutual relationship between $r$ and $\Delta_{\mathrm{r}} G$, the parameter of $M$ related to $K_{0}$ and $a_{\mathrm{OH}^{-}}$was set to build a function about reaction order $(n)$ as shown in Equation (12), where the reaction order can be obtained by changing the concentration of $\mathrm{OH}^{-}$. And the apparent activation energy is calculated at different temperatures, as shown in Equation (13) deriving from Equation (8).

$$
\begin{gathered}
M=K_{0} a_{\mathrm{OH}^{-}}^{n} \\
\ln M=\ln K_{0}+n \ln a_{\mathrm{OH}^{-}} \\
r=M\left\{1-\left[\exp \left(\mathrm{m} \Delta_{\mathrm{r}} G / \mathrm{RT}\right)\right]^{p}\right\}^{q} \\
\ln K_{0}=\ln \left(k_{0} \mathrm{~A}\right)-E_{a} / \mathrm{RT}
\end{gathered}
$$

As shown in Figure 5, the relationship between reaction Gibbs free energy $\left(\Delta_{\mathrm{r}} G\right)$ and reaction rate $(r)$ was built by the experiments under various concentrations of $\mathrm{OH}^{-}$ and various reaction temperatures. The values of $M$ listed in Table 6 at different $\mathrm{KOH}$ concentrations and various reaction temperatures can be obtained by the better fitting relationship between $r$ and $\Delta_{\mathrm{r}} G / \mathrm{RT}$. In Equation (12), the activity values of $\mathrm{OH}^{-}$are correlated with the reaction temperature, $\mathrm{KOH}$ concentration, and saturated vapor pressure. Based on Equation (12), the value of reaction order (n) obtained from the slope of the fitting straight line between $\ln M$ and $\ln a_{\mathrm{OH}^{-}}$is 2.992 (Figure 6a), and according to Equation (14), the apparent activation energy $\left(E_{\mathrm{a}}\right)$ calculated from the liner-fitting relationship of $\ln K_{0}-1 / T$ is $97.41 \mathrm{~kJ} / \mathrm{mol}$ (Figure $6 \mathrm{~b}$ ). Considering the apparent activation energy, the value of $E_{a}(97.41 \mathrm{~kJ} / \mathrm{mol})$ reveals a chemical reaction controlling the dissolution of feldspar. Hellmann [37] reported that the dissolution reaction order of albite under acidic, neutral and alkaline solutions are 4.4,3.3, and 3.8, respectively, as well as 
the apparent activation energy, are 89,69 and $85 \mathrm{~kJ} / \mathrm{mol}$, respectively. In conclusion, the concentrated alkaline solution under the hydrothermal condition was a major factor accelerating feldspar dissolution.
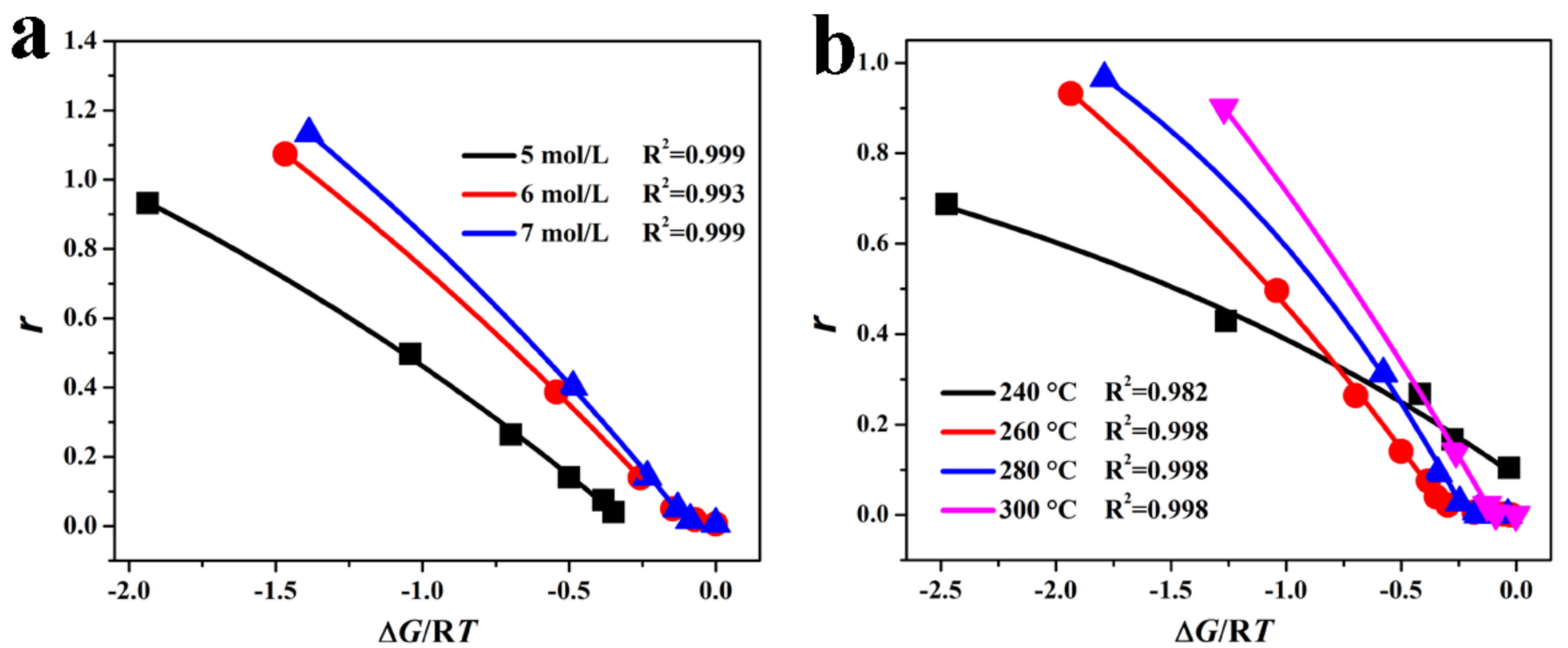

Figure 5. The relationship between dissolution reaction Gibbs free energy $\left(\Delta_{\mathrm{r}} G\right.$ and reaction rate $(r)$, (a) concentration-time series experiments, $(\mathbf{b})$ temperature-time series experiments.

Table 6. The fitting parameter $(\mathrm{M})$ and activity of $\mathrm{OH}^{-}$at different $\mathrm{KOH}$ concentration and reaction temperatures.

\begin{tabular}{ccccccc}
\hline \multirow{2}{*}{ Parameters } & \multicolumn{2}{c}{ KOH Concentration $(\mathbf{m o l} / \mathrm{L})$} & \multicolumn{3}{c}{ Reaction Temperature $\left({ }^{\circ} \mathrm{C}\right)$} \\
\cline { 2 - 7 } & $\mathbf{5 . 0}$ & $\mathbf{6 . 0}$ & $\mathbf{7 . 0}$ & $\mathbf{2 4 0}$ & $\mathbf{2 6 0}$ & $\mathbf{2 8 0}$ \\
\hline$M$ & 1.142 & 2.334 & 3.291 & 1.122 & 2.334 & 1.582 \\
$a_{\mathrm{OH}^{-}}$ & 0.422 & 0.551 & 0.593 & 0.638 & 0.551 & 0.466 \\
\hline
\end{tabular}
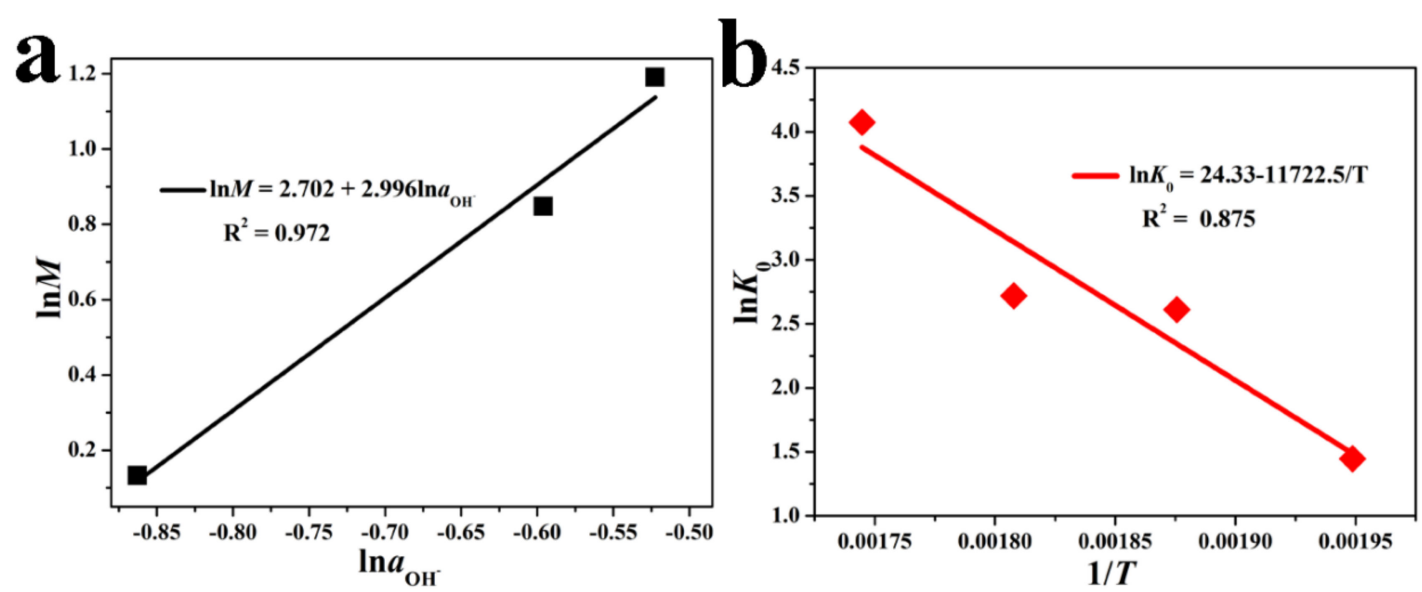

Figure 6. The plot of $\ln \mathrm{M}-\ln a_{\mathrm{OH}^{-}}(\mathbf{a})$ and $\ln K_{0}-1 / \mathrm{T}(\mathbf{b})$.

\section{Conclusions}

In summary, two kinds of $\mathrm{KAlSiO}_{4}$ were precipitated in the dissolution process of $\mathrm{K}$ feldspar and the dissolution reaction dynamic was studied by adopting the aluminosilicate mineral geochemical dissolution model. The results indicate that the MEK, an intermediate product, was generated during the transformation process from K-feldspar to kalsilite. Two kinds of $\mathrm{KAlSiO}_{4}$ obtained here are easier to be decomposed in the acid soil, which 
not only can supply potassium nutrition to plants but can ameliorate soil via the porous structure. In addition, the reaction order and apparent activation energy at the temperature range of $240-300{ }^{\circ} \mathrm{C}$ were simulated to be 2.992 and $97.41 \mathrm{~kJ} / \mathrm{mol}$, respectively. Compared with geochemical weathering process of K-feldspar, the high reaction order was considered to be the major factor promoting the rapid reaction.

The hydrothermal approach proposed in this study provides an appropriate and simplified way for the comprehensive utilization and clean production of K-silicates.

Author Contributions: Funding acquisition, Q.G.; investigation, Z.L.; supervision, H.M.; writingoriginal draft, J.Y.; writing — review and editing, H.M. and X.M. All authors have read and agreed to the published version of the manuscript.

Funding: The present work was funded by the Fundamental Research Funds for the Central Universities (2952016058, 2952016059) and National Natural Science Foundation of China project (41903049).

Institutional Review Board Statement: Not applicable.

Informed Consent Statement: Not applicable.

Acknowledgments: We thank Zheng Luo from China University of Geosciences, Beijing for their help in the hydrothermal experiment. The authors also appreciate Qian Guo at the Institute of Geology and Geophysics.

Conflicts of Interest: The authors declare no conflict of interest.

\section{References}

1. David, A.C.M. Mineral sources of potassium for plant nutrition. A review. Agron. Sustain. Dev. 2010, 30, $281-294$.

2. Skorina, T.; Allanore, A. Aqueous alteration of potassium-bearing aluminosilicate minerals: From mechanism to processing. Green Chem. 2015, 17, 2123-2136. [CrossRef]

3. Ma, H.W. Potassic Rocks in China: Resource and Clean Utilization Techniques; Chemical Industy Press: Beijing, China, 2010; pp. 1-39. (In Chinese)

4. Yuan, J.; Yang, J.; Ma, H.; Su, S.; Chang, Q.; Komarneni, S. Hydrothermal synthesis of nano-kaolinite from K-feldspar. Ceram. Int. 2018, 44, 15611-15617. [CrossRef]

5. Ma, H.W.; Yang, J.; Su, S.Q.; Liu, M.T.; Zheng, H.; Wang, Y.B.; Qi, H.B.; Zhang, P.; Yao, W.G. 20 years advances in preparation of potassium salts from potassic rocks: A review. Acta Geol. Sinica 2015, 89, 2058-2071.

6. Ma, H.W.; Yang, J.; Zhang, P.; Liu, C.J.; Su, S.Q.; Yao, W.G.; Luo, Z.; Liu, M.T.; Yin, C.C.; Chen, J.; et al. Potassic syenite resource in China and reaction mechanism of potash salt processing by hydrothermal alkaline digestion. Earth Sci. Front. 2018, 25, 277-285.

7. Ciceri, D.; Manning, D.A.C.; Allanore, A. Historical and technical developments of potassium resources. Sci. Total Environ. 2015, 502, 590-601. [CrossRef]

8. Mandarino, J.A.; Back, M.E. Fleischer's Glossary of Mineral Species; The Minerallogical Record Inc.: Tucson, AZ, USA, $2014 ;$ p. 420.

9. Guertal, E.A. Preplant slow-release nitrogen fertilizers produce similar bell pepper yields as split applications of soluble fertilizer. Agron. J. 2000, 92, 388-393. [CrossRef]

10. Shavit, U.; Shaviv, A.; Shalit, G.; Zaslavsky, D. Release characteristics of a new controlled release fertilizer. J. Control. Release 1997, 43, 131-138. [CrossRef]

11. Zhao, G.Z.; Liu, Y.Q.; Tian, Y.; Sun, Y.Y.; Cao, Y. Preparation and properties of macromelecular slow-release fertilizer containing nitrogen, phosphorus and potassium. J. Polym. Res. 2010, 17, 119-125. [CrossRef]

12. Tokunaga, Y. Potassium silicate: A slow-release potassium fertilizer. Nutr. Cycling Agroecosyst. 1991, 30, 55. [CrossRef]

13. Perez, M.G.; Rueda, J.I.P.; Mateos, F.B.; Marin, J.P. Slow-release fertilizer in the form of emulsion. Chem. Biochem. Eng. Q. 1999, 13, 21.

14. Mangrich, A.; Tessaro, L.; Anjos, A.D.; Wypych, F.; Soares, J. A slow-release $\mathrm{K}^{+}$fertilizer from residues of the Brazilian oil-shale industry: Synthesis of kalsilite-type structures. Environ. Geol. 2001, 40, 1030.

15. Ma, H.W.; Su, S.Q.; Yang, J.; Cai, B.; Liu, M.; Yao, W.; Peng, H. Preparation of potassium sulfate from K-feldspar by hydrothermal alkaline method: Reaction principle and process evaluation. Ciesc. J. 2014, 8, 91.

16. Ma, X.; Ma, H.W.; Yang, J. Sintering preparation and release property of $\mathrm{K}_{2} \mathrm{MgSi}_{3} \mathrm{O}_{8}$ slow-release fertilizer using biotite acidleaching residues as silicon source. Ind. Eng. Chem. Res. 2016, 55, 41. [CrossRef]

17. Ma, X.; Ma, H.; Yuan, J.; Guo, R. Synthesis of $\mathrm{K}_{2} \mathrm{O}-\mathrm{MgO}-\mathrm{SiO}_{2}$ compounds as slow-release fertilisers from acid-leached biotite residues. Ceram. Int. 2020, 46, 1403-1410. [CrossRef]

18. Hu, P.; Zhang, Y.; Wang, X.; Zhou, Y.; Tong, W.; Luan, X.; Zhao, P. $\mathrm{K}_{2} \mathrm{MgSi}_{3} \mathrm{O}_{8}$ in slow-release mineral fertilizer prepared by sintering of by-product of red mud-based flocculant. Environ. Eng. Sci. 2018, 35, 829-835. [CrossRef]

19. Bogdanovicienè, I.; Jankeviciutè, A.; Pinkas, J.; Kareiva, A. Sol-gel synthesis and characterization of kalsilite-type alumosilicates. Mater Sci. 2007, 13, 1392-11320. 
20. Dimitrijevic, R.; Dondur, V. Synthesis and characterization of $\mathrm{KAlSiO}_{4}$ polymorphs on the $\mathrm{SiO}_{2}-\mathrm{KAlO}_{2}$ join. J. Solid State Chem. 1995, 115, 214-224. [CrossRef]

21. Becerro, A.I.; Mantovani, M.; Escudero, A. Hydrothermal synthesis of kalsilite: A simple and economical Method. J. Am. Ceram. Soc. 2009, 92, 2204-2206. [CrossRef]

22. Burch, T.E.; Nagy, K.L.; Lasaga, A.C. Free energy dependence of albite dissolution kinetics at $80^{\circ}$ C. Chem. Geol. 1993, 105, 137-162. [CrossRef]

23. Fu, Q.; Lu, P.; Konishi, H.; Dilmore, R.; Xu, H.; Seyfried, W.E.; Zhu, C. Coupled alkali-feldspar dissolution and secondary mineral precipitation in batch systems: 1 . New experiments at $200{ }^{\circ} \mathrm{C}$ and 300 bars. Chem. Geol. 2009, 258, 125-135. [CrossRef]

24. Brachhold, N.; Aneziris, C.G. Synthesis of alkali aluminosilicates-Materials for alkali contaminated environments at high temperatures. Int. J. Appl. Ceram. Technol. 2013, 10, 707-715. [CrossRef]

25. Yuan, J.; Yang, J.; Ma, H.; Liu, C.; Zhao, C. Hydrothermal synthesis of analcime and hydroxycancrinite from K-feldspar in $\mathrm{Na}_{2} \mathrm{SiO}_{3}$ solution: Characterization and reaction mechanism. RSC Adv. 2016, 6, 54503-54509. [CrossRef]

26. Yuan, J.; Yang, J.; Ma, H.; Su, S.; Chang, Q.; Komarneni, S. Green synthesis of nano-muscovite and niter from feldspar through accelerated geomimicking process. Appl. Clay Sci. 2018, 165, 71-76. [CrossRef]

27. Liu, C.; Ma, H.; Zhang, P. Thermodynamics of the hydrothermal decomposition reaction of potassic syenite with zeolite formation. Wuli Huaxue Xuebao/Acta Phys. Chim. Sin. 2018, 34, 168-176. [CrossRef]

28. Liu, C.; Ma, H.; Gao, Y. Hydrothermal processing on potassic syenite powder: Zeolite synthesis and potassium release kinetics. Adv. Powder Technol. 2019, 30, 2483-2491. [CrossRef]

29. Su, S.Q.; Ma, H.W.; Chuan, X.Y.; Cai, B.Y. Preparation of potassium sulfate and zeolite NaA from k-feldspar by a novel hydrothermal process. Int. J. Miner. Process. 2016, 155, 130-135. [CrossRef]

30. Yuan, J.Y.; Ma, H.W.; Guo, R.Y.; Ma, X.; Komarneni, S. A case study targeting K fertilizer chemical synthesis with complete valorization of extraction by-products as an option. Green Chem. 2020, 22, 654-6966. [CrossRef]

31. Yuan, J.; Yang, J.; Ma, H.; Chang, Q. Preparation of Zeolite F as Slow Release Fertilizers from K-Feldspar Powder. ChemistrySelect 2017, 2, 10722-10726. [CrossRef]

32. Ma, H.W. Crystallographic Thermodynamics Software; Geological Publishing House: Beijing, China, 1999; pp. 1-15.

33. Yuan, J.; Yang, J.; Ma, H.; Liu, C. Crystal structural transformation and kinetics of NH 4+/Na+ ion-exchange in analcime. Microporous Mesoporous Mater. 2016, 222, 202-208. [CrossRef]

34. Larsen, A.C.; von Dreele, R.B. General Structure Analysis System; LANSCE, MS-H805; Los Alamos National Laboratory: Los Alamos, NM, USA, 1994.

35. Khomyakov, A.P.; Nechelyustov, G.N.; Sokolova, E. Megakalsilite, a new polymorph of $\mathrm{KAlSiO}_{4}$ from the Khibina alkaline massif, kola peninsula, Russia: Mineral description and crystal structure. The Candidate Mineralogist. Can. Miner. 2002, 40, 961-970. [CrossRef]

36. Andratschke, M.; Haase, H.; Klement, U. Die Kristallstruktur Von a-KZnPO4. In Zeitschrift für Naturforschung B; De Gruyter: Berlin, Germany, 1992; pp. 1249-1254.

37. Hellmann, R.; Tisserand, D. Dissolution kinetics as a function of the Gibbs free energy of reaction: An experimental study based on albite feldspar. Geochim. Cosmochim. Acta 2006, 70, 364-383. [CrossRef]

38. Beig, M.S. Feldspar Dissolution Kinetics and Eauilibrium. Ph.D. Thesis, Rice University, Houston, TX, USA, 2005.

39. Kremenović, A.; Vulić, P. Disordered kalsilite KAlSiO4. Acta Crystallogr. Sect. C Struct. Chem. 2014, 70, 256-259. [CrossRef] [PubMed]

40. Smith, J.V.; Bailey, S.W. Second review of Al-O and Si-O tetrahedral distances. Acta Crystallogr. 1963, 16, 801-811. [CrossRef]

41. Wen, G.; Yan, Z.; Smith, M.; Zhang, P.; Wen, B. Kalsilite based heterogeneous catalyst for biodiesel production. Fuel 2010, 89, 2163-2165. [CrossRef]

42. He, P.Y.; Zhang, Y.J.; Chen, H.; Han, Z.C.; Liu, L.C. Low-energy synthesis of kaliophilite catalyst from circulating fluidized bed fly ash for biodiesel production. Fuel 2019, 257, 116041. [CrossRef]

43. Kumar, P.; Singh, V.; Hira, S.; Manna, P.; Kumar, P. In vitro Cytotoxicity, Apoptotic and Hemolysis Assay of Kalsilite-Based Glass Ceramics for Dental Veneering Application. Int. J. Appl. Ceram. Technol. 2016, 13, 78-87. [CrossRef]

44. Kumar, P.H.; Singh, V.K.; Kumar, P. Mechanochemically synthesized kalsilite based bioactive glass-ceramic composite for dental vaneering. Appl. Nanosci. 2017, 7, 269-274. [CrossRef]

45. Oda, C.; Walker, C.; Chino, D.; Ichige, S.; Honda, A.; Sato, T.; Yoneda, T. Na-montmorillonite dissolution rate determined by varying the Gibbs free energy of reaction in a dispersed system and its application to a coagulated system in $0.3 \mathrm{M} \mathrm{NaOH}$ solution at $70{ }^{\circ}$ C. Appl. Clay Sci. 2014, 93, 62-71. [CrossRef]

46. Zeng, L.; Li, Z. Dissolution behavior of aluminum, silicon, and iron of diaspore concentrate in naoh-naal $(\mathrm{OH})_{4} \mathrm{Solutions}$ at elevated temperature. Ind. Eng. Chem. Res. 2013, 52, 18429-18439. [CrossRef]

47. Lasaga, A.C.; Soler, J.M.; Ganor, J.; Burch, T.E.; Nagy, K.L. Chemical weathering rate laws and global geochemical cycles. Geochim. Cosmochim. Acta 1994, 58, 2361-2386. [CrossRef]

48. Lasaga, A.C. Transition State Theory. Rev. Miner. 1981, 8, 135-136.

49. Alekseyev, V.A.; Medvedeva, L.S.; Prisyagina, N.I.; Balabin, A.I. Change in the dissolution rates of alkali feldspars as a result of secondary mineral precipitation and approach to equilibrium. Geochim. Cosmochim. Acta 1997, 61, 1125-1142. [CrossRef] 
50. Holland, T.J.B.; Powell, R. An internally consistent thermodynamic data set for phases of petrological interest. J. Metamorph. Geol. 1998, 16, 309-343. [CrossRef]

51. Wang, P.; Anderko, A.; Young, R.D. A speciation-based model for mixed-solvent electrolyte systems. Fluid Phase Equilib. 2002, 203, 141-176. [CrossRef]

52. Qun, P.A.N.; Hui, P.A.N.; Hong, L.U.; Jian, S.U.; Dong, C. Alkli—activated Mechanisms of Kaolinite and Hydrothermal Synthesis of 4A Zeolite. J. Mater. Sci. Eng. 2009, 1, 1-5. 